Microb Ecol (2000) 39:92-99

DOI: $10.1007 /$ s002489900185

(C) 2000 Springer-Verlag New York Inc.

\title{
Physiological Status and Community Composition of Microbial Mats of the Ebro Delta, Spain, by Signature Lipid Biomarkers
}

\author{
A. Navarrete, ${ }^{1}$ A. Peacock, ${ }^{2}$ S.J. Macnaughton, ${ }^{2}$ J. Urmeneta, ${ }^{1}$ J. Mas-Castellà, ${ }^{1}$ D.C. White,${ }^{2}$ \\ R. Guerrero ${ }^{1}$ \\ ${ }^{1}$ Department of Microbiology, University of Barcelona, Av. Diagonal 645, 08028 Barcelona, Spain \\ ${ }^{2}$ Center for Environmental Biotechnology, University of Tennessee, 10515 Research Drive, \\ Knoxville, TN 37932-2575, USA
}

Received: 14 May 1999; Accepted: 6 September 1999; Online Publication: 24 March 2000

A

Physiological status of microbial mats of the Ebro Delta (Tarragona, Spain) based on the extraction of lipids considered "signature lipid biomarkers" (SLB) from the cell membranes and walls of microorganisms has been analyzed. Data from a day-night cycle show significant differences in viable cells countings (PLFA cells counts) ranging from $1.5 \times 10^{10}$ to $5.0 \times 10^{10}$ cells $^{-1}$ of sediment. Minimum values were observed at 18:00 and 6:00, when physicochemical conditions change drastically. The diversity of the microbial community was assessed by GC/MS analysis of phospholipid fatty acids (PLFA). The ratio of PLFA, representative of Gram-negative bacteria, comprises $47.8 \%$ of the total PLFA of the microbial mat community. The remaining PLFA was representative of Gram-positive (10.0\%), anaerobic (5.7\%), and eukaryotic microorganisms (5.7\%), and other common lipids. Two different approaches were used as a comparative study to assess the physiological status of the microbial mats. Two parameters (cyclopropane fatty acids/ $\omega 7 \mathrm{c}$ monoenoic fatty acids, and measurement of the trans/cis monoenoic PLFA ratio) showed a minimum at midnight, suggesting the highest microbial activity. Higher values were observed at 18:00 and 6:00, coinciding with lower PLFA cell counts.

\section{Introduction}

The microbial community is an essential element in the trophodynamics of detrital and benthic ecosystems [10]. Changes in the structure and function relationships in this vital community have proven to be difficult to measure by

Correspondence to: A. Navarrete; Fax: 34-3-4021484; E-mail: tony@bio.ub.es methods that require isolation of the microorganisms from their microenvironment. Moreover, these approaches do not allow quantitative measurements [9]. These disruptive methods are suitable to estimate neither the total abundance nor the community composition within environmental samples. Unfortunately, morphology gives no indication of the function or of the state of metabolic activity for most of the major bacterial components of the community. Besides, viable or direct counts of bacteria attached to sediment 
grains are difficult to quantify, and so they could greatly underestimate the cell number and community composition $[1,5]$.

A microbial mat is a community composed primarily of different populations of bacteria, which form thin horizontal layers. These layers have active growth and can be several millimeters to a few centimeters thick. These layers develop along microgradients established at fluid interfaces (usually water, but occasionally vapor) on solid substrata. A steep redox gradient at the interface is established. Consequently, depletion of oxygen below the mat surface coincides with increases of sulfide (and often methane) with depth. Microbial mats developing in shallow waters are composed primarily of oxygenic cyanobacteria (in the upper layers), purple and green sulfur bacteria (in the middle layers), and sulfate-reducing bacteria (at the bottom). We also observed a population of heterotrophic and fermentative microorganisms and sulfur oxidizers that do not form stable layers and do not have a defined position in the mat. Methanogenic bacteria have also been detected in some microbial mats [26]. Some eukaryotic organisms, such as the amoebamastigote Paratetramitus jugosus and the ciliate Pseudocohnilembus pusillus [25], are associated with microbial mats. Microbial mats can be found in different locations in the Iberian Peninsula [23]. However, those found in La Banya spit, at the south end of the Ebro Delta [16], are probably the most extensive, stable, well developed, and morphologically varied. Chemical analysis of sediments can indicate function or metabolic activity in prokaryotes, as morphology cannot [3, 33]. Lipids, especially fatty acids, have proven to be of great value in the understanding of phylogenetic and taxonomic classifications [20, 21, 30, 34]. The lipid analysis has been applied to assess microbial communities (bacteria, fungi, protozoa, and metazoa) in mud, soil, rhizosphere, sediments, and bioreactors $[32,34]$. The signature lipid biomarkers (SLB) analysis provides a quantitative means of measuring viable microorganisms $[1,11,13]$, microbial community composition [13,34], and community nutritional/ physiological status $[15,31]$. Extractable phospholipids have been proposed as indicators of microbial abundance. Unlike most other biomarkers, phospholipids are quickly degraded (ranging from minutes to a few hours after cell death) [35]. This rapid degradation of phospholipids to diglycerides makes phospholipid fatty acids excellent biomarkers for viable cells.

Different groups of microorganisms synthesize a variety of PLFAs through various biochemical pathways [36]. This makes PLFAs effective taxonomic markers, useful to define community composition. However, there is an overlap in PLFA composition between different species, and as such, it is not possible to define each species with a unique pattern of PLFA. Only approximately $1-5 \%$ of the organisms in the total sedimentary community have actually been isolated and have had their PLFAs analyzed [36].

The aim of this study is to characterize the microbial community of the mats in La Banya spit of the Ebro Delta by determining its microbial composition, physiological status, and day-night variations. Two different approaches to assess the physiological status of the microbial mats have been compared: determination of the formation of cyclopropane fatty acids from their monoenoic homologues, and measurement of the ratio of trans/cis monoenoic PLFA.

\section{Methods}

\section{Microbial Mats: Site and Sampling}

The microbial mats studied are located in the coastal area of the Ebro Delta (Tarragona, Spain) $\left(40^{\circ} 40^{\prime} \mathrm{N}, 0^{\circ} 40^{\prime} \mathrm{E}\right)$. The general features of this natural microbial community in terms of species composition, population dynamics, and physicochemical characterization have been described earlier [16, 23]. Sediment samples were taken during the spring of 1997, over a day-night cycle. The upper $3 \mathrm{~cm}$ of the mat was sampled (three cores at each time) every 6 hours starting at midday (12:00, 18:00, 24:00, 6:00, and 12:00 of the following day) using a $5 \mathrm{~cm}$ inner-diameter methacrylate corer. Samples were frozen in liquid nitrogen, transported to the laboratory within $2 \mathrm{~h}$ after collection, and lyophilized in a Virtis apparatus (at $-55^{\circ} \mathrm{C}$ and 200 mtorr).

Physicochemical conditions of the overlying water $(1 \mathrm{~cm}$ from the sediment-water interface) were analyzed at each sampling time. A CRISON OXI-92 oxymeter was used to measure both temperature and oxygen. A LICOR LI-189 meter was used to measure solar irradiation. Sulfide concentration was measured by the Pachmayr colorimetric method [27], according to the following protocol. One $\mathrm{ml}$ of the water sample was added in situ to a $125 \mathrm{ml}$ bottle which contains $20 \mathrm{ml}$ of zinc acetate solution $(2 \% \mathrm{w} / \mathrm{v})$ and transported to the laboratory. Once in the laboratory, distilled water was added to around $80 \mathrm{ml}$. Afterwards $10 \mathrm{ml}$ of dimethylparaphenylene diaminesulfate (DPDS) $(0.2 \% \mathrm{w} / \mathrm{v})$ solution and $0.5 \mathrm{ml}$ of ferric ammonium sulfate $(10 \% \mathrm{w} / \mathrm{v})$ was added to the bottle. The mixture was shaken vigorously, and distilled water was added to a final volume of $100 \mathrm{ml}$. Absorbance at $663 \mathrm{~nm}$ was measured after 15 min of incubation. Sulfide concentration was calculated by the following equation:

$$
\begin{gathered}
\left(\text { Abs }-\mathrm{Abs}_{\text {white }}\right) \times 0.027 \times 100 / \mathrm{V}_{\text {sample }}(\text { in } \mathrm{ml}) \\
=\text { Sulfide concentration }(\text { in } \mathrm{mM})
\end{gathered}
$$




\section{Lipid Analysis}

Each lyophilized sample was detached to process the main microbial populations of the community. Samples were pulverized separately using sterile tools in order to keep background levels of PLFA as low as possible. All solvents used were GC grade and were obtained from Fisher Scientific (Pittsburgh, PA). In addition, all glassware was thoroughly cleaned and heated in a muffle furnace at $450^{\circ} \mathrm{C}$ for at least $4 \mathrm{~h}$ prior to use. Microbial mat samples (three replicates of $0.3 \mathrm{~g}$ of dry weight of each core) were extracted using a modified Bligh and Dyer procedure as described by White and collaborators in 1979 [33]. The total lipids obtained were then fractionated into glyco-, neutral-, and polar lipids [14]. The polar phospholipid fatty acids were then transesterified into methyl esters [14].

Gas chromatography (GC) analysis of fatty acid methyl esters was carried out on a Hewlett-Packard 5890 Series II GC with a flame ionization detector. The GC was programmed from an initial temperature of $60^{\circ} \mathrm{C}$ to $280^{\circ} \mathrm{C}$, at $10^{\circ} \mathrm{C}$ per min, and then held at this temperature for $3 \mathrm{~min}$. The helium carrier gas flow rate was 1.5 $\mathrm{ml} \mathrm{min}{ }^{-1}$ at $0.92 \mathrm{~kg} \mathrm{~cm}^{-2}$. The injection port was at $270^{\circ} \mathrm{C}$ and the detector at $290^{\circ} \mathrm{C}$.

Gas chromatography/mass spectrometry (GC/MS) analysis of fatty acid methyl esters was carried out on a Hewlett-Packard 5890 Series II GC interfaced with a HP 5973 Series mass selective detector (Hewlett-Packard, Wilmington, DE) [35]. Electron impact mass spectrometry was performed at $70 \mathrm{eV}$. The ion source was held at $200^{\circ} \mathrm{C}$, with the electron multiplier voltage at 3,000 V.

Fatty acids were identified by relative retention times, by comparison with authentic standards (Matreya Inc., Pleasant Gap, PA) and by the mass spectral analysis. Fatty acid nomenclature is in the form of "A:B $\omega C$ " where " $A$ " designates the total number of carbons, " $B$ " the number of double bonds, and " $C$ " the distance of the closest unsaturation from the aliphatic end of the molecule. The suffixes " $c$ " for cis and " $\mathrm{t}$ " for trans refer to geometric isomers. The prefixes "i", "a," and "me" refer to iso and anteiso methyl branching, and midchain methyl branching, respectively, with cyclopropyl rings indicated by "cy" [19].

\section{Cell Number Estimation}

A conversion factor was used to transform quantities of PLFA obtained into numbers of cells. It was assumed that there were 2.5 $\times 10^{12}$ cells per gram of dry weight, and $10^{8}$ pmol PLFA per gram of dry weight [1]. This yields $2.5 \times 10^{4}$ cells per pmol of PLFA. Note that with any conversion factor, the number of cells can vary by up to one order of magnitude [12].

\section{Statistics}

Results were analyzed using correlation statistics and analysis of variance (ANOVA). These analyses were applied to determine significant differences between samples through time, and possible relationships between PLFA profiles. All statistical analyses were performed using Microsoft Excel 5.0 for Macintosh (Microsoft Corporation, 1985-1994).

\section{Results \\ External Conditions}

Starting at 12:00, solar light, measured on the sampling point, decreased reaching a minimum value at 24:00 (Fig. 1). Oxygenic photosynthesis decreased as the net oxygen concentration decreased. Temperature also decreased because of the lack of solar light. Sulfide was first detected at 24:00 and was at its maximum $(30 \mu \mathrm{M})$ at 6:00. Sulfide production during the day was neutralized by the spontaneous reaction with dissolved oxygen and by consumption by anoxygenic photosynthetic bacteria. The following morning temperature and light intensity values rose again to a maximum of $25^{\circ} \mathrm{C}$ and $2100 \mu \mathrm{E} \mathrm{m} \mathrm{m}^{-2} \mathrm{~s}^{-1}$, respectively. Dissolved oxygen concentration also increased the morning after and sulfide decreased to undetectable limits.

\section{Cell Number Estimates and Microbial Community Composition}

Viable cell estimates are given as the number of cells estimated from PLFA data (Fig. 2). They ranged from $1.5 \times 10^{10}$ to $5.0 \times 10^{10}$ cells $\mathrm{g}^{-1}$ dry weight. Significant differences were detected at the 6-hour sampling intervals. Maximum cell number values $\left(5.0 \times 10^{10}\right.$ cells $\mathrm{g}^{-1}$ dry weight $)$ were observed at 12:00 and 24:00. Minimum values were observed at

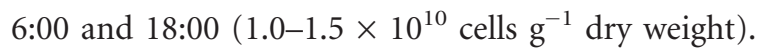

Characterization of the microbial mats using PLFA analysis indicated the presence of a diverse microbial community (Table 1). The community consisted primarily of gramnegative bacteria (including cyanobacteria), as evidenced by the presence of monoenoic PLFAs [37], which comprised $47.8 \% \pm 3.8 \%$ of the total PLFA. PLFAs typical of Grampositive bacteria (terminally branched saturated fatty acids) [24] comprised $10.0 \% \pm 2.6 \%$ of the total PLFAs; however, terminally branched saturated fatty acids have also been associated with the presence of gram-negative anaerobic bacteria [37]. Lipids representative of anaerobic microorganisms, including the branched monosaturates and midchain branched saturates $[7,8]$, comprised $5.7 \% \pm 1.6 \%$ of the total PLFAs. Lipids representative of sulfate-reducing bacteria comprised $22.2 \% \pm 3 \%$ of the total lipids of anaerobic microorganisms. Although biomarkers indicative of anaerobic microbiota dropped to minimum levels by 24:00, relative proportions of the PLFA biomarkers remained relatively constant during the day-night cycle. Relative proportions of 

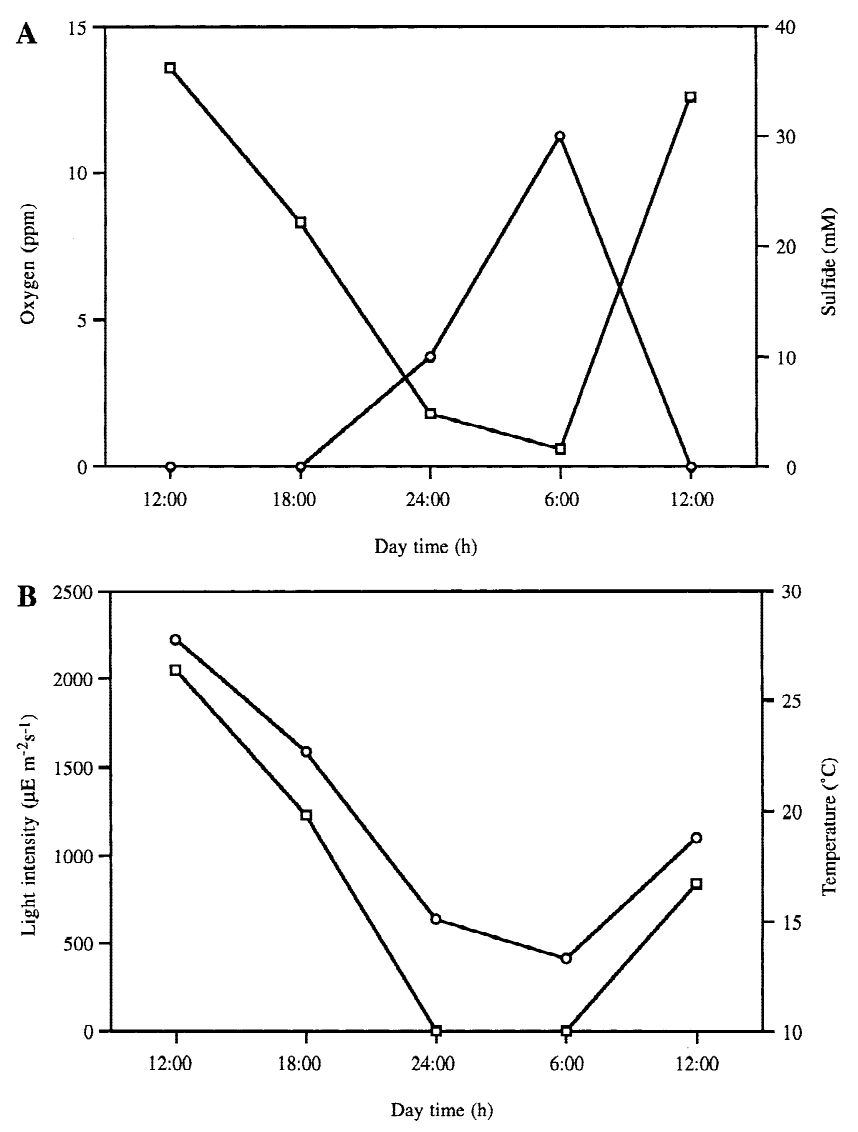

Fig. 1. Physicochemical conditions in the overlying water of microbial mats during day/night cycle. (A) $-\square-$ oxygen, $-\mathrm{O}-$ hydrogen sulfide; (B) $-\square-$ light intensity, $-\mathrm{O}-$ temperature.

polysaturated fatty acids, representative of cyanobacteria [4] as well as eukaryotic microorganisms, were constant $(5.7 \% \pm$ $1.5 \%)$ at all sampling times except at 24:00 (8.1\%). Normal saturated fatty acids $(26.4 \%)$ are present in both eukaryota and prokaryota and therefore cannot be used in community structure analysis.

\section{Physiological Status of Microbial Mats}

The knowledge of specific lipid biosynthetic pathways can provide insight into the physiological or nutritional status (bioavailability of elements, such as carbon and nitrogen) of the microbial community. Certain fatty acids can be used as indicators of environmental stress. Exposures to toxic environments can lead to minicell formations and a relative increase in trans-monoenoic PLFAs when compared with the cis homologues. Other PLFA patterns also change in response to environmental stress. Prolonged exposure to conditions inducing stationary growth phase induce the forma- tion of cyclopropane PLFA. Ratios of cyclopropane fatty acids to their monoenoic homologues show an increase in response to changes of environmental conditions $[15,18,31$, $35]$. The monoenoic fatty acids $(16: 1 \omega 7 \mathrm{c}$ and $18: 1 \omega 7 \mathrm{c})$ are converted to cyclopropyl (cy 17:0 and cy 19:0). This change is expressed in two ratios (cy 17:0/16:1 $\omega 7 \mathrm{c}$ and cy 19:0/ $18: 1 \omega 7 \mathrm{c})$ and represents the shift to conditions which slow down the growth rate. Monoenoic PLFA to cyclopropane PLFA rates of the samples are shown in Fig. 3. The minimum reading was detected in samples taken at 24:00. Maximum values, indicating the slowest growth rates, were observed at 6:00 and 18:00 in the transient phase between day and night. Metabolic stress of the sampled microbial mats, expressed as a trans/cis monoenoic PLFA ratio, is shown in Fig. 4. Again the lowest value was observed at 24:00, which indicates a low level of stress on the microbial community at that time. Ratios ranged from 0.055 to 0.08 .

\section{Discussion \\ External Conditions}

Physicochemical conditions within the mat (Fig. 1) were derived from the complex microbial activity in this kind of community. The main microbial metabolic activities detected are oxygenic and anoxic photosynthesis and sulfate reduction. Therefore, in order to gain a better understanding of the functioning of microbial mats, a knowledge of their physiological state is crucial.

\section{Cell Number Estimates and Microbial Community Composition}

As in any ecological system, microbial mat dynamics is the result of the influence of the different factors that interact in

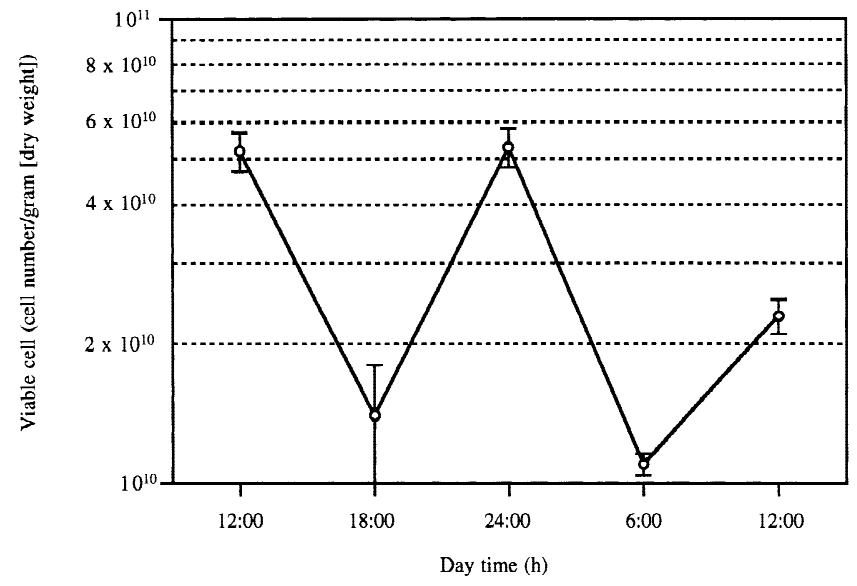

Fig. 2. Viable cell numbers obtained from PLFA direct determination. 
Table 1. Community composition approach (percentage of lipid biomarkers during a day/night cycle)

\begin{tabular}{|c|c|c|c|c|c|c|}
\hline PLFA biomarkers & Group of organisms & \multicolumn{5}{|c|}{ Day time $(\mathrm{h})$} \\
\hline Monoenoics & Gram negatives & $53.36 \pm 0.27$ & $47.53 \pm 0.57$ & $48.62 \pm 0.50$ & $47.04 \pm 0.37$ & $42.58 \pm 0.68$ \\
\hline Terminally branched saturates & Gram positives & $6.79 \pm 0.21$ & $12.36 \pm 0.33$ & $7.91 \pm 0.16$ & $10.35 \pm 0.55$ & $12.57 \pm 0.58$ \\
\hline Midchain branched saturates & Anaerobes & $2.89 \pm 0.06$ & $3.51 \pm 0.18$ & $3.59 \pm 0.02$ & $5.37 \pm 0.17$ & $4.88 \pm 0.17$ \\
\hline Other lipids & & $2.13 \pm 0.10$ & $5.55 \pm 0.06$ & $1.66 \pm 0.13$ & $6.70 \pm 0.20$ & $3.63 \pm 0.21$ \\
\hline
\end{tabular}

its habitat. The development of the mat is ruled by the functioning of the many different microbial populations (diatoms, cyanobacteria, purple and green sulfur bacteria, sulfate reducers, heterotrophs, methanogens, etc.) that coexist within this complex system. Each of these populations has its own growth and death rates, which depend on the physicochemical conditions of the habitat.

A major problem when measuring viable cells using biochemical techniques is the fact that the results are in micromoles of component per gram of sediment or soil. A simple conversion could be done by determining the biomarker content of monocultured cells and then counting the cells to determine a value per cell [2]. Microbial mat sediment samples were shown to contain sparse prokaryote communities of minicells (observed microscopically). The viable cell number determined by PLFA was equivalent (with a smaller standard deviation) to that estimated by intracellular ATP, cell wall muramic acid, and AODC measurements [1]. It was assumed that there were $2.5 \times 10^{12}$ cells per gram of dry weight, and that $1 \mathrm{~g}$ (dry weight) of cells [1] was equivalent to $10^{8}$ pmol PLFA, which means that 1 pmol of PLFA is equivalent to $2.5 \times 10^{4}$ cells [12].

To determine the community composition by using a signature lipid approach, it is crucial to consider the environment from which the sample was retrieved when interpreting the results. The analysis of SLB by GC/MS provides sufficient information to detect broad subsets of the microbial community that allow quantitative definition of the community. Community composition can be characterized from the pattern and types of PLFA identified in samples [14]. Monoenoic PLFA are found in almost all Gramnegative microorganisms and many types of eukaryotic microorganisms. The $\omega 9$ monoenoic PLFAs are formed from the aerobic desaturase pathway common to all cells, whereas the $\omega 7$ PLFAs are formed from the anaerobic desaturase pathway, which is often a prokaryotic biochemical pathway
[32]. Branched-chain monoenoic PLFAs are common in the anaerobic Desulfovibrio-type sulfate reducing bacteria both in culture and in manipulated sediments $[8,28]$. They are also found in certain actinomycetes, which, as a group, contain midchain branched saturated PLFAs, in particular 10Me18:0, with lower amounts of 10 other methyl-branched homologues.

Environments with a large ratio of 10Me16:0 often feature anaerobic Gram-negative Desulfobacter-type sulfate reducing bacteria $[7,28]$. Polysaturated fatty acids indicate the presence of cyanobacteria and eukaryotic microorganisms [5]. Polyenoic PLFAs have also been sparingly reported in some bacteria [36]. Polyenoic PLFAs with the first unsaturation in the $\omega 6$ position are classically considered to be of animal origin, whereas organisms with the first unsaturation in the $\omega 3$ position are generally considered to be of either plant or algal origin. Normal saturated PLFA longer than 20 carbons are typical of the microeukaryotes.

\section{Physiological Status of Natural Communities}

The monoenoic PLFAs $16: 1 \omega 7 \mathrm{c}$ and $18: 1 \omega 7 \mathrm{c}$ are increasingly converted to the cyclopropyl fatty acids cy17:0 and cy19:0, respectively, in Gram-negative bacteria as the microbes move from a logarithmic to a stationary phase of growth. This ratio (growth without cell division) varies from organism to organism and from environment to environment, but usually falls within the range of 0.05 (log phase) to 2.5 or higher (stationary phase) [22]. Slow growth can occur in microbes when carbon source(s) and terminal electron acceptors are present but some essential nutrients are not available. Under these conditions of "unbalanced growth," bacterial can accumulate biopolymers (such as poly- $\beta$ hydroxyalkanoates [6]). An increase in cyclopropyl PLFA formation has also been associated with an increased anaerobic metabolism in facultative heterotrophic bacteria in monoculture studies [32]. 


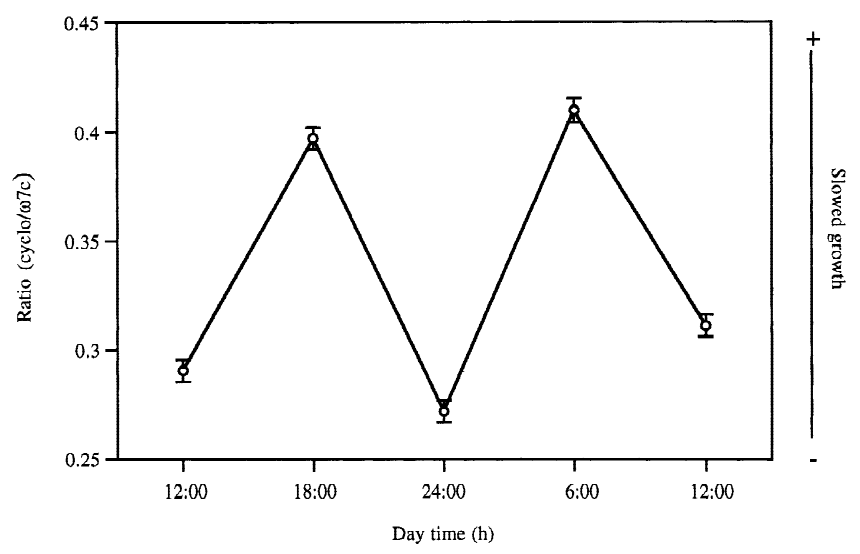

Fig. 3. Metabolic status expressed by relationship between cyclopropyl fatty acids and monoenoic PLFAs.

Bacteria produce trans-monounsaturated fatty acids as a result of metabolic stress (e.g., toxicity, starvation) [17]. In addition, trans/cis ratios higher than 0.1 indicate starvation in bacterial isolates. This value is usually 0.05 or less in healthy, nonstressed populations.

The 18:00 time point showed an increase of metabolic stress (Fig. 4), and a shift to slow growth was observed. At 6:00 another inflection point in the viable cells (PLFA cell counts) was detected, which coincided with an increase in the metabolic stress and in the anaerobic bacteria proportion (Table 1). During the day, oxygenic and anoxygenic photosynthesis predominates over aerobic respiration and sulfatereduction activity in the microbial mat ecosystem. Excess carbon assimilates which were not used for growth accumulated in the cells as biopolymers (stress observed at 18:00). At the end of the day, when the light intensity decreases dras-

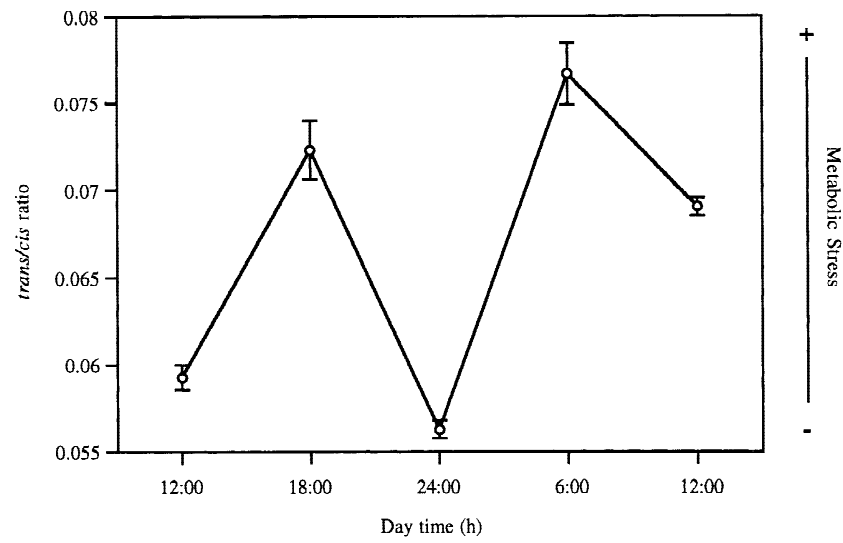

Fig. 4. Metabolic status expressed by relationship between trans/ cis conformations of monoenoic PLFAs. tically, and also during the night, the respiratory and sulfate reduction activity predominate because the photosynthesis is stopped. Anoxic conditions during the night may also trigger the development of sulfate reducing bacteria which may become very active using the organic matter (reduced products) generated during the day as electron donors for sulfate reduction. In these conditions, sulfide concentration increases and oxygen and readily assimilated organic carbon are quickly depleted inside the mat (stress maximum observed at 6:00).

Sensitive analytical procedures have been developed for the quantitative study of natural microbial communities in situ. Although these methods cannot answer all experimental questions regarding natural microbial communities, they do provide a good set of tools for studying microbes and microbial communities. These methods can provide quantitative data on the status and role of these main ecosystem components.

The biochemical assays described in this study estimate the microbial abundance without any need for microbial growth or for the quantitative recovery of microbes from surfaces on which they grow. These methods of signature analysis are proving to be helpful in determining the structure of microbial communities. By correlating measurements of nutritional status with metabolic activity, this type of biochemical analysis can also help to unravel problems associated with the accurate estimation of true in situ microbial activity.

The application of sensitive analytical methods to natural microbial communities is just beginning. As methods improve both in sensitivity and in selectivity and the catalogues of signature lipids increase, a deeper insight of the complex microbial communities that drive the biogeochemical cycles of this planet will be possible.

\section{Acknowledgments}

We thank the Parc Natural del Delta de l'Ebre of the Generalitat de Catalunya for giving permission to enter and collect samples in the bird sanctuary of La Banya spit. We thank Professor Steve Goodwin (University of Amherst, MA, USA), and Professor Marie-Odile Soyer-Gobillard (Observatoire Oceanologique Banyuls, France) for their help supplying us with complementary data, and Mercè Piqueras, Carolina C. Campbell, and Frances Luttikhuizen for their assistance in editing the manuscript. Part of this work was supported by grants to R.G. from the Spanish Interministe- 
rial Commission for Science and Technology (CYCIT, AMB95-0516), from the European Associated Laboratory (LEA, Marine Sciences) between Spain and France, and from the IC18-CT97-0201 program INCO-DC.

\section{References}

1. Balkwill DL, Leach FR, Wilson JT, McNabband JF, White DC (1988) Equivalence of microbial biomass measures based on membrane lipid and cell wall components, adenosine triphosphate, and direct counts in subsurface sediments. Microb Ecol $16: 73-84$

2. Brinch-Iverson J, King GM (1990) Effects of substrate concentration, growth state, and oxygen availability on relationships among bacterial carbon, nitrogen and phospholipid phosphorous content. FEMS Microbiol Ecol 74:345-356

3. Bobbie RJ, White DC (1980) Characterization of benthic microbial community structure by high-resolution gas chromatography of fatty acid methyl esters. Appl Environ Microbiol 39:1212-1222

4. Caudales R, Wells JM (1992) Differentiation of free-living Anabaena and Nostoc cyanobacteria on the basis of fatty acid composition. Int J Syst Bacteriol 42:246-251

5. Colwell RR, Brayton PR, Grimes DJ, Rozak DB, Huq SA, Palmer LM (1985) Viable but non cultured Vibrio cholerae and related pathogens in the environment: Implications for the release of genetically engineered microorganisms. Biotechnology 3:817-820

6. Doi Y (1990) Microbial Polyesters. VCH Publishers, New York, pp 1-8

7. Dowling NJE, Widdel F, White DC (1986) Phospholipid esterlinked fatty acid biomarkers of acetate-oxidizing sulfate reducers and other sulfide forming bacteria. J Gen Microbiol 132:1815-1825

8. Edlung A, Nichols PD, Roffey R, White DC (1985) Extractable and lipopolysaccharide fatty acids and hydroxy acid profiles from Desulfovibrio species. J Lipid Res 26:982-988

9. Esteve I., Gaju N, Mas-Castellà J, Guerrero R, Margulis L (1995) Bacterial survival mechanisms in microbial mats. Microbiología SEM 11:397-399

10. Fenchel TM, Jørgensen BB (1977) Detritus food changes of aquatic ecosystems the role of bacteria. Adv Microb Ecol 1:158

11. Findlay RH, King GM, Watling L (1989) Efficiency of phospholipid analysis in determining microbial biomass in sediments. Appl Environ Microbiol 55:2888-2893

12. Findlay RH, Dobbs FC (1993) Quantitative description of microbial communities using lipid analysis. In: Kemp PF, Sherr BF, Sherr EB, Cole JJ (eds) Handbook of Methods in Aquatic Microbial Ecology. Lewis Publishers, Boca Raton, FL, pp 271284

13. Fredrickson JK, Mckinley JP, Nierzwicki-Bauer SA, White DC,
Ringelberg DB, Rawson SA, Li S-M, Brockman FJ, Bjornstad BN (1995) Microbial community structure and biogeochemistry of miocene subsurface sediments: implications for longterm microbial survival. Mol Ecol 4:619-626

14. Guckert JB, Antworth CP, Nichols PD, White DC (1985) Phospholipid, ester-linked fatty acid profiles as reproducible assays for changes in prokaryotic community structure of estuarine sediments. FEMS Microbiol Ecol 31:147-158

15. Guckert JB, Hood MA, White DC (1986) Phospholipid, esterlinked fatty acids profile changes during nutrient deprivation of Vibrio cholerae: Increases in the trans/cis ratio and proportions of cyclopropyl fatty acids. Appl Environ Microbiol 52:794-801

16. Guerrero R, Urmeneta J, Rampone G (1993) Distribution of types of microbial mats at the Ebro Delta, Spain. BioSystems 31:135-144

17. Heipieper HJ, Diffenbach R, Keweloch H (1992) Conversion of cis unsaturated fatty acids to trans, a possible mechanism for the protection of phenol-degrading Pseudomonas putida P8 from substrate toxicity. Appl Environ Microbiol 58:1847-1852

18. Jacques NA, Hunt AL (1980) Studies on cyclopropane fatty acid synthesis: effect of carbon source and oxygen tension on the accumulation of methylene hexadecanoic acid by Pseudomonas denitrificans. Biochim Biophys Acta 619:453-470

19. Kates S (1986) Techniques of Lipidology Isolation, Analysis and Identification of Lipids, 2nd ed. Elsevier, Amsterdam

20. Lechevalier MP (1977) Lipids in bacterial taxonomy-a taxonomist's view. Crit Rev Microbiol 7:109-210

21. Lechevalier H, Lechevalier MP (1988) Chemotaxonomic use of lipids-an overview. In: Ratledge C, Wilkinson SG (eds) Microbial Lipids. Academic Press, London, pp 869-902

22. Mickell AT, Phelps TJ, White DC (1987) Phospholipids to monitor microbial ecology in anaerobic digesters. In: Smith WH, Frank JR (eds) Methane from Biomass, a System Approach. Elsevier, New York, pp 413-444

23. Mir J, Martínez-Alonso M, Esteve I, Guerrero R (1991) Vertical stratification and microbial assemblage of a microbial mat in the Ebro Delta (Spain). FEMS Microbiol Ecol 86:59-98

24. O'Leary WM, Wilkinson SG (1988) Gram-positive bacteria. In: Ratledge C, Wilkinson SG (eds) Microbial Lipids, Vol 1. Academic Press, London, pp 117-201

25. Olendzenski L, Urmeneta J (1993) Selected organisms from the microbial mats of Baja California (Mexico) and Ebro Delta (Spain). In: Guerrero R, Pedrós-Alió C (eds) Trends in Microbial Ecology. Spanish Society for Microbiology, Barcelona, pp 543-546

26. Oremland RS, King GM (1989) Methanogenesis in hypersaline environments. In: Cohen Y, Rosenberg E (eds) Microbial Mats: Physiological Ecology of Benthic Microbial Communities. American Society for Microbiology, Washington DC, pp $180-190$

27. Pachmayr F (1960) PhD thesis, University of Munich, Munich, Germany 
28. Parkes RJ, Dowling NJE, White DC, Herbert RA, Gibson GR (1992) Characterization of sulfate-reducing bacterial populations within marine and estuarine sediments with differents rates of sulfate reduction. FEMS Microbiol Ecol 102:235-250

29. Ringelberg DB, Sutton S, White DC (1997) Biomass, bioactivity and biodiversity: Microbial ecology of the deep subsurface: Analysis of ester-linked phospholipid fatty acids. FEMS Microbiol Rev 20:371-377

30. Shaw N (1974) Lipid composition as a guide to the classification of bacteria. Adv Appl Microbiol 17:63-108

31. Sikkema J, de Bont JAM, Poolman D (1995) Mechanisms of membrane toxicity of hydrocarbons. Microbiol Rev 58:201222

32. Tunlid A, White DC (1991) Biochemical analysis of biomass, community structure, nutritional status, and metabolic activity of the microbial communities in soil. Bollag JM, Stotzky G, (eds) Soil Biochem, Vol. 7. Marcel Dekker, New York, pp 229-262

33. White DC, Davis WM, Nickels JS, King DJ, Bobbie RJ (1979)
Determination of the sedimentary microbial biomass by extractible lipid phosphate. Oecologia 40:51-62

34. White DC, Stair JO, Ringelberg DB (1996) Quantitative comparisons of in situ microbial biodiversity by signature biomarker analysis. J Ind Microbiol 17:185-196

35. White DC, Ringelberg DB (1997) Utility of the signature lipid biomarker analysis in determining the in situ viable biomass, community structure and nutritional/physiologic status of deep subsurface microbiota In: Amy PS, Haldeman DL (eds) The Microbiology of the Terrestrial Deep Subsurface. Lewis Publishers, Boca Raton, FL, pp 119-136

36. White DC, Ringelberg DB, MacNaughton S, Alugupalli SJ, Schram D (1997) Signature lipid biomarker analysis for quantitative assessment in situ of environmental microbial ecology. In: Eganhouse RP (ed) Molecular Markers in Environmental Geochemistry, Vol 2. pp 22-34

37. Wilkinson SG (1988) Gram negative bacteria. In: Ratledge C, Wilkinson SG (eds) Microbial Lipids, Vol 1. Academic Press, London, pp 299-488 